Wiktor Ross

\title{
INSTYTUCJA PREZYDENTA W SYSTEMIE POLITYCZNYM FEDERACJI ROSYJSKIEJ
}

\section{System sowiecki i prezydentura}

Instytucja prezydenta jako głowy państwa jest w Rosji instytucją nową, powstałą w okresie reform ustrojowych poprzedzających rozpad Związku Sowieckiego. Jej utworzenie było w pewnym stopniu zabiegiem mającym na celu zahamowanie procesów destrukcji zmurszałego reżimu komunistycznego i jego rewitalizację. Tymczasem wbrew intencjom jej inicjatora - Sekretarza Generalnego KPZS, Michaiła Gorbaczowa - walka o kształt prezydentury stała się elementem dynamizującym procesy rozpadu starej państwowości, ujawniającym głębokie sprzeczności systemu sterowania procesami decyzyjnymi na wszystkich poziomach organizacji społecznej - w gospodarce, sferze politycznej i socjalnej.

Mimo iż instytucja prezydentury w niektórych republikach została wprowadzona nawet nieco wcześniej niż w Federacji Rosyjskiej, to jednak przemiany polityczne i instytucjonalne w Rosji miały charakter określający dla kierunku przeobrażeń na całym obszarze Związku Sowieckiego. Z tego względu wymagają one bardziej szczegółowej analizy i ukazania politycznego kontekstu oraz ewolucji instytucji prezydenta w ZSRS i FR.

W tradycji ustrojowej Związku Sowieckiego nie istniała instytucja jednoosobowej głowy państwa jako najwyższego urzędu państwowego. Po okresie totalnej negacji zasad ustrojowych powszechnych w państwach demokratycznych, podczas prac nad Konstytucją ZSRS z 1936 r. (zwaną "stalinowską", choć jej głównym autorem był Nikołaj Bucharin), powstały pewne próby połączenia sowieckiego jednolitego systemu władzy państwowej z typową dla Zachodu zasadą podziału władz, w postaci poszukiwania dróg wmontowania w ten system „obcej” dlań instytucji prezydenta wybieranego w wyborach powszechnych ${ }^{1}$. Nie było to jednak bynajmniej

1 B. Łazariew, Prezidient SSSR, „Sowietskoje gosudarstwo i prawo” nr 7, Moskwa 1990, s. 3. 
poszukiwanie kompromisu między systemem sowieckim i demokracją zachodnią, lecz wyraz konsolidacji systemu totalitarnego w latach 30., nadawania mu cech „stateczności", co znajdowało wyraz m.in. w kreowaniu nowych podziałów społecznych i odpowiadających im norm statusu społecznego, materialnego, prestiżowego, heroizacji imperialnych cech monarchii carów, rezygnacji z rewolucyjnych innowacji w nazewnictwie rang wojskowych i biurokratycznych na rzecz tradycyjnych form, słowem maskowaniu istotnych cech totalitaryzmu pozorami „normalności”. Idea ta pozostała jednak tylko w sferze projektu, któremu sprzeciwiał się sam Józef Stalin, twierdząc, że w ZSRS niepotrzebna jest instytucja jednoosobowego prezydenta wybieranego na równi z Radą Najwyższąa . Tym samym utrzymana została instytucja „kolegialnej prezydentury” w postaci Prezydium Rady Najwyższej wraz z jej przewodniczącym, mającym ograniczone uprawnienia głównie o charakterze ceremonialnym.

Próby połączenia funkcji sekretarza generalnego partii i prezydenta państwa były podejmowane także w latach 60 ., w okresie sprawowania władzy przez Nikitę Chruszczowa, ale nie zostały one uwieńczone powodzeniem. Nieobecność instytucji prezydenta w systemie ustrojowym państw komunistycznych nie była jednak zupełnie sztywną zasadą narzucaną tym państwom przez imperium sowieckie. W Czechosłowacji istniała ona przez cały okres powojenny, a w Rumunii została wprowadzona przez Nicolae Ceausescu w 1974r. Także w Polsce funkcję tę w latach 1945-1952 pełnił, jak wiadomo, Bolesław Bierut.

\section{Rola instytucji prezydenta w okresie prób przebudowy systemu sowieckiego}

W schyłkowej fazie istnienia imperium sowieckiego instytucja prezydenta miała odegrać inną rolę. $Z$ jednej strony ku jednoosobowej formie sprawowania władzy, wolnej od wszelkich pseudodemokratycznych pozorów, jakimi obwarowana była władza sekretarza generalnego partii komunistycznej w postaci jej Zjazdu, Komitetu Centralnego i Biura Politycznego, kierowała cała tradycja rosyjskiego samowładztwa. Późnosowieckie społeczeństwo nie posiadało wypracowanych jawnych legalnych mechanizmów reprezentacji interesów politycznych, które mogłyby być konkurencyjne wobec odgórnej władzy jednostki symbolizującej jedność narodową i nadającej kierunek rozwojowi państwa, zwłaszcza w obliczu jego totalnego kryzysu. Istotną rolę $\mathrm{w}$ wyborze takiego modelu reformowania struktury instytucji

2 J. Stalin, Zagadnienia leninizmu, Książka i Wiedza, Warszawa 1949, s. 532. 
państwa odgrywały z pewnością także zachodnie wzorce, którym modernistyczna elita sowiecka coraz bardziej ulegała w okresie intensywnego dialogu politycznego między Michaiłem Gorbaczowem i prezydentem USA, Ronaldem Reaganem, rozstrzygającym losy nowej architektury bezpieczeństwa światowego i sfer wpływu, łącznie z takimi podstawowymi sprawami, jak zjednoczenie Niemiec i destrukcja komunistycznych form integracji militarnej i ekonomicznej. Przywódcom zachodnim zależało głównie na utrzymaniu wewnętrznej stabilności imperium sowieckiego zagrożonego wybuchem politycznym, społecznym i narodowościowym na niespotykaną skalę. Jednoznaczne przywództwo, jeśli nie faktycznie, to przynajmniej formalnie legitymizowane $\mathrm{w}$ okresie transformacji ustrojowej, posiadało $\mathrm{w}$ tym procesie ogromne znaczenie i instytucja prezydenta państwa zastępującego przywódcę skompromitowanej partii komunistycznej była nader poręcznym instrumentem.

Najważniejszym wszakże czynnikiem tworzenia tej instytucji było przekonanie sowieckich elit polityczno-gospodarczych, iż prezydent stanowi najlepszą formę gwarancji ich interesów w dokonującej się rynkowej transformacji ustroju ekonomicznego - przejściu od systemu centralnego planowania do quasi-konkurencyjnej struktury gospodarczej, w której realne zmiany form własności przeplatały się z licznymi „uznaniowymi” instrumentami dzielenia przywilejów i uprawnień w postaci przyjętych procedur prywatyzacji mienia państwowego, licencji (na przykład eksportowych), zamówień państwowych na produkcję i świadczenie usług, zwolnień od świadczeń, ulg podatkowych itp. ${ }^{3}$

Warto zwrócić uwagę na fakt, iż tendencje te ujawniły się nie tylko w Rosji, będącej katalizatorem rewolucyjnych przeobrażeń, a wręcz przeciwnie, zapoczątkowane one zostały w innych republikach sowieckich, gdzie - oprócz tych „ogólnosystemowych” prawidłowości - określoną rolę odgrywał także czynnik nacjonalistyczny lub tradycjonalistyczny związany właśnie z brakiem nawyków demokratycznych. Trudno uznać za przypadek fakt, iż instytucję prezydenta jako pierwszy w kwietniu $1990 \mathrm{r}$. wprowadził Kazachstan, a w ślad za nim Kirgizja, Turkmenistan, Uzbekistan i Mołdawia. Nieco później instytucja prezydenta pojawiła się w państwach bałtyckich, a dopiero w 1994 r. na Białorusi. W większości wypadków funkcje prezydenckie przejmował były I sekretarz republikańskiej partii komunistycznej, co dobitnie podkreśla „nomenklaturowy" charakter tej przemiany instytucjonalnej opartej na szerokim konsensusie elit polityczno-gospodarczych. Tam, gdzie sytuacja wymknęła się spod kontroli, jak w państwach Zakaukazia, na ogół wracała ona w utartą koleinę po krótkim okresie eksperymentów (przypadek A. Elczibeja w Azerbejdżanie, Z. Gamsachurdii w Gruzji czy nieco dłuższy epizod prezydentury L. Ter-Petrosjana w Armenii).

3 Szeroko na ten temat w: W. Marciniak, Rozgrabione imperium. Upadek Zwiazzu Sowieckiego i powstanie Federacji Rosyjskiej, Wyd. Arcana, Kraków 2001. 
Mimo tych kuluarowych uzgodnień należy także dostrzegać oddolny, demokratyczny charakter rozwijających się w końcu lat 80 . masowych ruchów politycznych i narodowych, nawiązujących do zachodniej tradycji demokratycznej i żądających pełnej parlamentarnej reprezentacji interesów politycznych, wyrażających zróżnicowanie sił społecznych i ich orientacji światopoglądowych. Ruchy te, tzw. Fronty Narodowe, dążyły już do stworzenia systemu politycznego opartego na zasadzie podziału władz, nie przesądzając, która z gałęzi władzy może okazać się najbardziej kreatywna. Problemem tych ruchów był jednak obiektywnie słaby poziom zróżnicowania struktury społecznej oraz zdolności rozmaitych grup do agregowania i artykulacji swych żądań i programów politycznych ${ }^{4}$.

W tej sytuacji struktura prezydencka, wyposażona w silny aparat administracyjny, gremia eksperckie złożone z najbardziej fachowych i zorientowanych na umiarkowane reformy doradców, okazywała się najbardziej efektywną konstrukcją prawno-polityczną dla przeprowadzenia kontrolowanej zmiany nienarażonej na zbyt silną presję ze strony szerokich warstw społecznych.

Na XIX Konferencji Partyjnej w 1988 r. w atmosferze tzw. pierestrojki przyjęto uchwałę o demokratyzacji społeczeństwa sowieckiego i reformie systemu politycznego, która była sygnałem do dokonania nowelizacji konstytucji. Wprowadziła ona istotne zmiany w systemie organów państwa, najwyższym organem władzy czyniąc Zjazd Deputowanych Ludowych (ZDL), liczący 2250 deputowanych, którzy otrzymywali mandat w „częściowo” demokratycznych wyborach. Był to system kurialny, w którym dwie trzecie jego składu wybierano w okręgach jednomandatowych w systemie większościowym. Pozostali byli delegowani przez partię komunistyczną oraz organizacje społeczne ${ }^{5}$. Ciało to wybierało Najwyższy Sowiet, który był organem odmiennym od dotychczasowego o tej samej nazwie. 542 członków tego ciała wybierano ze składu ZDL. Prezydium Najwyższego Sowietu miało za zadanie organizowanie prac ZDL i NS, a wraz ze swoim przewodniczącym pełniło funkcję zbiorowej głowy państwa. Przewodniczący wybierany był w tajnym głosowaniu na pięć lat i mógł pełnić swą funkcję nie więcej niż przez dwie kadencje.

Była to swoista „przymiarka” do wprowadzenia instytucji prezydenta państwa, gdyż kompetencje przewodniczącego Prezydium NS były zakreślone bardzo szeroko. Kierował on pracami NS, sprawował kontrolę nad merytorycznym zakresem prac ZDL i NS, udzielał informacji o stanie państwa, podpisywał akty prawne przyjęte

4 Demokracje Europy Środkowo-Wschodniej w perspektywie porównawczej, red. A. Antoszewski, R. Herbut, Wyd. Uniwersytetu Wrocławskiego, Wrocław 1998, s. 53.

5 Jak widać z powyższego, częściowo demokratyczne wybory do Sejmu RP z 4 czerwca 1989 r. nie były zupełnie oryginalnym pomysłem polskim, lecz oparte były na podobnej zasadzie, jak ta, którą wprowadziła znowelizowana w 1988 r. konstytucja sowiecka. 
przez najwyższe organy ustawodawcze, a także proponował im kandydatury na najwyższe stanowiska państwowe. Przewodniczący Prezydium NS miał także prawo inicjatywy ustawodawczej i wydawania rozporządzeń. Przysługiwały mu również kompetencje w prowadzeniu polityki zagranicznej.

Nowela konstytucyjna stanowiła oczywiście postęp w dziedzinie demokratyzacji życia politycznego w ZSRS, ale głęboka jego przemiana w takiej strukturze instytucjonalnej nie była możliwa. Władzy chodziło nie o rzeczywistą demokratyzację poprzez ujawnienie wszystkich sił i tendencji, jakie kryły się w społeczeństwie sowieckim, lecz o oswojenie elementów dysydenckich wywodzących się ze struktur sowieckich i kooptację ich w ramy polityczno-ideologiczne tworzone przez reformistyczne skrzydło partii komunistycznej. W ten sposób wyłoniła się Międzyregionalna Grupa Deputowanych skupiająca najbardziej aktywne jednostki, uczestniczące w debacie publicznej o demokratyzacji życia politycznego ze słynnym uczonym i działaczem ruchu dysydenckiego Andriejem Sacharowem na czele. Przewodniczącym Prezydium NS został M. Gorbaczow, co miało ugruntować jego pozycję i umocnić mandat do kontynuowania procesu reform społecznych w obliczu oporu sił konserwatywnych. Nowa sytuacja polityczna, wpływająca nie tylko na układ sił w Związku Sowieckim, relacje między Moskwą i republikami związkowymi, ale także na cały blok wschodni, otworzyła jednak pole konfliktów, których nie można już było powstrzymać metodą modernizacji systemu komunistycznego. Eklektyczna forma ustrojowa, łącząca funkcje głowy państwa i szefa parlamentu, nie pozwalała na skuteczne przezwyciężanie permanentnego kryzysu politycznego. W obliczu zagrożenia wprowadzeniem w życie idei A. Sacharowa, by wybierać prezydenta państwa w wyborach powszechnych, co ze względu na rosnącą popularność Borysa Jelcyna mogłoby zagrozić pozycji Gorbaczowa, wystąpił on z kontrpropozycją, by prezydenta wybierał Zjazd Deputowanych Ludowych ${ }^{6}$.

\section{Michaił Gorbaczow - pierwszy i ostatni prezydent ZSRS}

Po zaznaczonej silnymi kontrowersjami dyskusji na temat możliwości łączenia funkcji prezydenta $\mathrm{z}$ funkcją sekretarza generalnego partii komunistycznej oraz sposobu jego wybierania w wyborach powszechnych i bezpośrednich lub pośrednich

6 J.L. Kuzniecow, Iz istorii sozdanija instituta prezidienta SSSR, „Gosudarstwo i prawo” nr 5, Moskwa 1996, s. 96. 
(przez ZDL) 15 marca 1990 r. Zjazd Deputowanych Ludowych wybrał M. Gorbaczowa na stanowisko prezydenta Związku Sowieckiego ${ }^{7}$.

Najbardziej charakterystyczną cechą tej formy ustrojowej było połączenie tradycyjnego dla zbudowanego hierarchicznie państwa komunistycznego, jednolitego systemu władz (sowietów) z instytucją prezydenta jako głowy państwa. Konstrukcja taka nie wprowadzała zasady podziału władz na niezależne od siebie gałęzie, a jedynie stwarzała taki pozór, nadal zostawiając systemowi sowietów, z ZDL na czele, połączone funkcje ustawodawcze, wykonawcze i kontrolne $e^{8}$. Przyznanie szerokich prerogatyw prezydentowi prowadziło nie do balansu i wzajemnego hamowania niezależnych od siebie władz reprezentujących wolę narodu jako suwerena, lecz do sporów kompetencyjnych i walki między gałęziami władzy, za którymi kryły się nieartykułowane w sposób jawny interesy grup konserwatywnych i reformatorskich.

Dążąc do opanowania dynamiki procesów politycznych pogłębiających kryzys państwa, prezydent Gorbaczow podjął kroki poszerzające zakres swojej władzy. W marcu 1990 r. uchwalono nowelizację konstytucji znoszącą „kierowniczą rolę partii”. Spowodowało to proces formalnej zmiany ośrodka decyzyjnego w państwie, przenosząc jego ciężar w kierunku instytucji prezydenta. Na czwartej sesji ZDL przyjęto kolejną nowelizację konstytucji, przyznając prezydentowi prawo kierowania rządem mimo zachowania stanowiska premiera. Obok istniejących już instytucji Rady Prezydenckiej i Rady Federacji utworzono także Radę Bezpieczeństwa, a także przyznano prezydentowi specjalne uprawnienia do wprowadzania reform gospodarczych. W doborze kadr do tych instytucji M. Gorbaczow kierował się względami taktycznymi, wprowadzając tam zarówno konserwatystów, jak i reformatorów. Zasadą było jednak przejmowanie potrzebnych mu ludzi $z$ aparatu partyjnego, nie zaś tworzenie kanałów dla generowania nowej elity rządzącej.

Najważniejszą kwestią, która dawała M. Gorbaczowowi azyl wobec sił totalitarnych w partii i strukturach siłowych, było utrzymanie jedności kraju, co było zadaniem coraz trudniejszym w obliczu umacniania sił odśrodkowych w republikach oraz w nowym kierownictwie Rosyjskiej Federacji z Borysem Jelcynem na czele. Działania w tym kierunku, w postaci referendum o utrzymaniu Związku Sowieckiego i negocjacji o nowym układzie związkowym z szefami republik, M. Gorbaczow inicjował bez konsultacji z ciałami ustawodawczymi, podobnie jak pakiet reform ekonomicznych przyjmowany w formie dekretów prezydenckich. Było to pogwałcenie reguł konstytucyjnych $\mathrm{w}$ relacjach między organami władzy prowadzące do obniżenia statusu ciał wybieralnych na czele z ZDL. W obliczu takich działań

7 Wybór prezydenta przez Zjazd Deputowanych Ludowych został potraktowany jako wyjątek spowodowany szczególną sytuacją polityczną. Kolejne wybory miały już mieć charakter powszechny.

8 A. Czajowski, Demokratyzacja Rosji w latach 1987-1999, Wyd. Atla 2, Wrocław 2001, s. 313. 
deputowani przenieśli swoją aktywność na poziom władz republikańskich lub zdecydowali się na poparcie zamachu stanu jako formy przezwyciężenia kryzysu konstytucyjnego".

Napięcie w stosunkach między władzami Rosji i centrum związkowym rosło w całym dwuletnim okresie lat 1990 i 1991. Było ono wynikiem sukcesów organizacyjnych ruchu demokratycznego głównie w Moskwie i Leningradzie, gdzie skupiała się główna część demokratycznej elity intelektualnej Rosji. Wybory na ZDL RFSRS w marcu 1990 r. przyniosły zdecydowane zwycięstwo tym siłom. Konserwatywny zwrot w polityce prezydenta Gorbaczowa, ulegającego elementom konfrontacyjnym w kierownictwie ZSRS, wyrażający się m.in. w próbie interwencji przeciw ruchom niepodległościowym w Wilnie i Rydze oraz przeprowadzeniu referendum w sprawie utrzymania w zmodyfikowanej formie Związku Sowieckiego, doprowadził do podjęcia walki o uzyskanie niezależności politycznej od związkowego centrum i tworzenia niezależnych struktur władzy. Walka ta dała rezultaty w postaci wyboru B. Jelcyna na stanowisko przewodniczącego Prezydium NS RFSRS i przyjęcia Deklaracji o suwerenności państwowej Rosji 12 czerwca 1990 r., a następnie do rozpoczęcia prac nad Ustawą o prezydencie RFSRS. W referendum na temat potrzeby instytucji prezydenta Rosji 70\% wyborców opowiedziało się za wprowadzeniem tej instytucji ${ }^{10}$.

Po przyjęciu Ustawy o Prezydencie RFSRS przez Najwyższy Sowiet, 24 maja 1991 r. na IV Zjeździe Deputowanych Ludowych, wprowadzono odpowiednie poprawki do konstytucji. Władza prezydenta podlegała silnej kontroli parlamentarnej. Prezydent określany był jako „najwyższa osoba urzędowa”, a nie „głowa państwa", jak było to ujęte w Konstytucji ZSRS. Prezydent wybierany był w wyborach powszechnych nie więcej niż na dwie kadencje. Kandydatem mógł być obywatel między 35 a 65 rokiem życia. Ustawa zakazywała równoczesnego pełnienia innych funkcji państwowych i uczestnictwa w organizacjach społecznych, a w przypadku przynależności do partii politycznej - nakazywała zawieszenie swego członkostwa na czas pełnienia urzędu prezydenta, choć nie była to zasada wpisana do Konstytucji RFSRS ${ }^{11}$.

Prezydent miał prawo, za zgodą Najwyższego Sowietu, desygnować premiera i nominować członków rządu, a także zdymisjonować rząd. Uprawnienia prezydenta

9 W. Marciniak, op.cit., s. 553.

10 Podobna liczba wyborców w Rosji wypowiedziała się za utrzymaniem państwa związkowego. Postawienie tego pytania w referendum było wynikiem kompromisu między konserwatystami i demokratami. Rezultat ten nie powinien jednak dziwić, jako że nawet B. Jelcyn po objęciu prezydentury nie był zwolennikiem rozpadu ZSRS, a nawet przestrzegał siły separatystyczne przed możliwością wybuchu wojny domowej.

11 W przypadku B. Jelcyna, który został pierwszym prezydentem RFSRS, nie było to konieczne, gdyż w sposób demonstracyjny wystąpił on z partii komunistycznej już w 1989 r. 
RFSRS wobec władzy wykonawczej stawały się większe w porównaniu z Konstytucją ZSRS, w której administracja była podporządkowana władzy ustawodawczej. W Rosji prezydent kierował pracami rządu i przedstawiał NS propozycje zmian w jego składzie. Prezydent stał także na czele Rady Bezpieczeństwa, do której prócz niego wchodzili: wiceprezydent, premier i I z-ca przewodniczącego NS, a także członkowie powołani przez prezydenta.

Prezydent wykonywał funkcje reprezentacyjne w stosunkach z zagranicą oraz posiadał prawo ogłaszania stanu wyjątkowego. W zakresie władzy ustawodawczej miał prawo wydawania dekretów i rozporządzeń, które mogły być uchylane przez NS w razie ich niezgodności z prawem. Prezydent miał także prawo inicjatywy ustawodawczej i prawo weta wobec ustaw przyjmowanych przez Najwyższy Sowiet. Do odrzucenia weta potrzebne było uzyskanie zwykłej większości w obu izbach NS. Ustawa przewidywała procedurę impeachmentu w przypadku rażącego naruszenia prawa przez prezydenta, stwierdzonego przez Sąd Konstytucyjny. Dla skutecznego odsunięcia prezydenta od władzy potrzebne było uzyskanie dwóch trzecich głosów uczestników Zjazdu.

\section{Walka polityczna o kształt nowego systemu prezydenckiego}

W wyborach prezydenta RFSRS w dniu 12 czerwca 1991 roku zwyciężył B. Jelcyn, który uzyskał 57,3\% głosów. Aktywne działania B. Jelcyna spowodowały, że w dniu 21 sierpnia 1991 roku konserwatywne siły we władzach Związku Sowieckiego podjęły próbę zamachu stanu i zawrócenia z drogi reform. Utworzono Państwowy Komitet Stanu Wyjątkowego, do którego weszły najważniejsze osoby w państwie, oprócz nieobecnego prezydenta M. Gorbaczowa, a więc - wiceprezydent Giennadij Janajew, premier Walentin Pawłow, minister obrony Dmitrij Jazow, szef KGB Władimir Kriuczkow, minister spraw wewnętrznych Borys Pugo.

Klęska puczystów pozwoliła prezydentowi B. Jelcynowi, który stanął na czele walki z próbą przywrócenia systemu totalitarnego i stał się symbolem reform demokratycznych, znacznie poszerzyć zakres władzy przyznanej mu w Konstytucji RFSRS. Na V Zjeździe Deputowanych Ludowych w październiku 1991 r. prezydent Jelcyn otrzymał nadzwyczajne uprawnienia na okres roku, które pozwalały mu zmieniać strukturę administracji rządowej oraz wydawać dekrety w obszarze gospodarki. $\mathrm{Na}$ tej podstawie B. Jelcyn wydał dekrety - o reorganizacji rządu RFSRS i o organizacji pracy rządu RFSRS, które stworzyły nową konstrukcję administracji państwowej, 
silnie podporządkowaną prezydentowi. Były to ministerstwa, komitety państwowe, służby i agencje federalne ${ }^{12}$.

Reformy te tworzyły zręby systemu organów państwowych, który miał w znacznym stopniu zachować się w nowym państwie rosyjskim już po rozpadzie ZSRS. Zmiany tych struktur w istniejącym jeszcze Związku Sowieckim nadal jednak przebiegały dwutorowo. I tak na przykład, na Nadzwyczajnym Zjeździe Deputowanych Ludowych ZSRS we wrześniu 1991 r. przyjęto Ustawę o organach władzy państwowej i zarządzania ZSRS w okresie przejściowym, która za jedyny organ władzy ustawodawczej uznawała Najwyższy Sowiet, faktycznie likwidując tym samym ZDL ZSRS. Zlikwidowano także Radę Bezpieczeństwa, którą zastąpiła Rada Państwowa, do której wchodzili prezydent ZSRS i szefowie republik. Jej zadaniem było określanie głównych kierunków polityki wewnętrznej i zagranicznej. Faktycznym celem było utrzymanie kontaktu M. Gorbaczowa z przywódcami usamodzielniających się republik sowieckich, aby utrzymać państwo związkowe, któremu M. Gorbaczow chciał nadać charakter Związku Suwerennych Państw (SSG). W tym celu zainicjował on spotkania w Nowo-Ogariewie pod Moskwą. Chęć tworzenia nowej struktury wyrażali jednak tylko przywódcy Białorusi i pięciu republik środkowoazjatyckich. Idea ta ignorowana była natomiast przez nowe władze Rosji, co nadawało jej charakter zupełnie iluzoryczny. Władze te przejmowały coraz więcej atrybutów władzy z rąk kierownictwa ZSRS i prezydenta Gorbaczowa. Okres tego dualizmu instytucjonalnego został przerwany wskutek zerwania przez przywódców Rosji, Białorusi i Ukrainy Układu Związkowego z 1922 r. o utworzeniu Związku Socjalistycznych Republik Sowieckich. Utworzyli oni zarazem Wspólnotę Niepodległych Państw jako zalążek nowej struktury integracji na nowych zasadach byłych republik sowieckich. Dnia 12 grudnia Najwyższy Sowiet RFSRS wydał uchwałę o wyjściu republiki rosyjskiej z ZSRS, a 25 grudnia M. Gorbaczow wydał oświadczenie o złożeniu urzędu prezydenta nieistniejącego już państwa związkowego. Tym samym prezydent RFSRS został prawnym sukcesorem pełni suwerennej władzy w państwie $\mathrm{z}$ tym wyposażeniem prawno-instytucjonalnym, które było uzyskane w złożonym procesie jego zdobywania.

O ile w początkowym okresie silniejszą pozycję w nowym systemie posiadała władza ustawodawcza, to jest Najwyższy Sowiet w tym składzie, w jakim był on wybrany w częściowo tylko demokratycznych wyborach, o tyle w kolejnych miesiącach rosyjska prezydentura $\mathrm{w}$ tym kształcie, $\mathrm{w}$ jakim została ona wprowadzona w połowie 1991 r., a następnie umocniona dekretami prezydenckimi po puczu sierpniowym, umocniła swoją realną władzę w państwie. Prezydent w ramach

12 W Marciniak, op.cit., s. 148-149. 
ustanowionego przez konstytucję porządku prawnego mógł skutecznie wpływać na Radę Ministrów, a także ustanowił własną Administrację Prezydenta ${ }^{13}$.

W znacznym stopniu działał on także metodami niekonstytucyjnymi, korzystając ze sprzeczności między grupami interesów w elicie polityczno-gospodarczej oraz z nieokreśloności całego pola prawno-konstytucyjnego. W ten sposób prezydent podporządkował sobie wydziały administracyjne i gospodarcze rządu i Najwyższego Sowietu oraz przejął znaczną część majątku partii na rzecz swojej administracji. Instytucja ta, mająca charakter nomenklaturowy, ulegała stałemu wzmocnieniu, by w latach późniejszych stać się najbardziej wpływową w państwie, zarówno w czasie prezydentury B. Jelcyna, jak i W. Putina.

Należy mieć na uwadze fakt, iż swoista rosyjska forma parlamentaryzmu, na którą składała się nowa instytucja, jaką był Zjazd Deputowanych Ludowych, oraz tradycyjna - Najwyższy Sowiet, pełniła nie tylko właściwe funkcje ustawodawcze, ale miała także szerokie kompetencje w obszarze władzy wykonawczej, głównie o charakterze politycznym i personalnym. ZDL wybierał władze i członków NS, wybierał sędziów Sądu Konstytucyjnego, zatwierdzał premiera oraz miał prawo impeachmentu prezydenta, a także mógł uchylać ustawy NS i dekrety prezydenta. NS akceptował kandydaturę premiera wysuniętego przez prezydenta, wybierał sędziów Sądu Najwyższego i Arbitrażowego, kontrolował fundusze pozabudżetowe, Bank Centralny i Urząd Statystyczny. Instytucja Przewodniczącego NS była projektowana w pierwszym etapie reform jako organ będący jednoosobową głową państwa i przez to wyposażona $\mathrm{w}$ instrumenty prawne, które ułatwiały rywalizację o władzę z utworzoną potem instytucją prezydenta. Wszystkie te zmiany doprowadziły do tego, że zasada jednolitości systemu władz, charakterystyczna dla epoki sowieckiej, została zastąpiona zasadą podziału władzy. Musiało to prowadzić do narastania konfrontacji między prezydentem i jego administracją a NS, w którym bardzo duże wpływy zachowały siły konserwatywne i postkomunistyczne.

W ramach rozwijającego się systemu podziału władz jako zasady ustrojowej silną pozycję uzyskał też Sąd Konstytucyjny, w skład którego wchodziło 13 nieusuwalnych sędziów. SK rozstrzygał spory między NS a prezydentem i, dzięki prerogatywie kontroli konstytucyjności dekretów, mógł unieważnić dekrety prezydenta. SK angażował się jednak w walkę między NS a prezydentem w sposób stronniczy i nie wykorzystał szansy na uzyskanie pełnej niezależności jako samodzielna gałąź władzy.

Nie ulega wątpliwości, że dynamika epoki historycznej sprzyjała prezydentowi, dając mu do ręki więcej instrumentów do kreowania nowych stosunków

${ }^{13}$ Istniała także funkcja wiceprezydenta Rosji. Stanowisko to objął gen. Aleksiej Ruckoj, który poparł B. Jelcyna w czasie puczu, ale potem stał się jednym z jego głównych przeciwników i współorganizatorem oporu NS przeciw prezydentowi w kolejnej próbie puczu w październiku $1993 \mathrm{r}$. 
własnościowych i repartycji stosunków władczych. Prezydent posiadał więcej uprawnień pozwalających mu pozyskiwać poparcie elit regionalnych dzięki możliwości ogłaszania wyborów do władz lokalnych i mianowania szefów lokalnych egzekutyw. Mógł „kupować” także ich życzliwość, przekazując im, w ramach realizowanej reformy gospodarczej o mało czytelnych zasadach i jeszcze mniej określonych procedurach, część prywatyzowanego majątku państwowego ${ }^{14}$.

Zapoczątkowanie zaprojektowanych przez wicepremiera Jegora Gajdara głębokich reform gospodarczych w 1992 r., którym „osłonę" polityczną stwarzał prezydent B. Jelcyn, w krótkim czasie skonsolidowało grupy interesu sprzeciwiające się liberalnym reformom. Prywatyzacja własności, tworzenie otoczenia rynkowego, antyinflacyjna polityka równoważenia budżetu państwa przez cięcie wydatków publicznych i blokowanie dostępu do dotacji państwowych - uderzało w interesy grup nomenklaturowych zarządzających takimi sektorami, jak kompleks wojskowo-przemysłowy i agrarny. Organizacje pracodawców skupiających te potężne siły stanowiły bazę poparcia dla konserwatywnych sił politycznych w Najwyższym Sowiecie.

B. Jelcyn nie zdołał oprzeć się tej presji i odszedł ze stanowiska szefa rządu, dając sygnał, że przestaje patronować polityce ekonomicznej rządu, ale - pozostawiając J. Gajdarowi funkcję p.o. prezesa rady ministrów i dokonując roszad kadrowych stanowiących ustępstwo wobec nomenklatury - próbował kontynuować reformy, stabilizując układ polityczny.

W tym czasie trwały prace nad projektem nowej Konstytucji Federacji Rosyjskiej, która miała zatwierdzić zmiany ustrojowe w nowych realiach politycznych. Nie została ona jednak przyjęta przez VI Zjazd Deputowanych Ludowych w kwietniu 1992 r., gdyż kompromisowy projekt przewidujący półprezydencki system władzy ze zrównoważonym układem pełnomocnictw legislatywy i prezydentury nie satysfakcjonował żadnej ze stron. B. Jelcyn wolał raczej zmieniać starą sowiecką konstytucję z 1978 r. i, korzystając z istniejących nadzwyczajnych pełnomocnictw, jeszcze bardziej rozszerzać zakres swojej władzy ${ }^{15}$. Spiker NS, Rusłan Chasbułatow, chciał natomiast uczynić ZDL najwyższą władzą w państwie, która stałaby na czele jednolitej struktury ustawodawczej i wykonawczej, nie zmieniając w istocie natury systemu sowieckiego, mimo rozwiązania partii komunistycznej i upadku totalitarnej ideologii. B. Jelcynowi, który skorzystał z rozbicia organizacyjnego opozycyjnych frakcji w NS, udało się przeforsować własną koncepcję.

Na VII ZDL w grudniu 1992 r. doszło do konfrontacji, w wyniku której deputowani nie przedłużyli prezydentowi jego nadzwyczajnych pełnomocnictw oraz

\footnotetext{
14 Ibidem, s. 297.

15 Th.F. Remington, The Politics of Institutional Choice: The Formation of the Russian State Duma, Princeton University Press, Princeton 2001, s. 5.
} 
wprowadzili w życie ustawę o Radzie Ministrów, która podporządkowywała rząd ZDL, NS i prezydentowi równocześnie. Prezydent utracił monopol na kontrolowanie rządu. NS uzyskał prawo powoływania i odwoływania premiera i jego zastępców oraz ministrów kluczowych resortów. Mógł także na mocy orzeczenia SN unieważnić dekrety i rozporządzenia prezydenta. $Z$ oporem deputowanych spotkały się wszystkie propozycje B. Jelcyna, jak wybór premiera przez Zjazd oraz kandydatura J. Gajdara na premiera. B. Jelcynowi nie udało się także zerwać obrad tego Zjazdu mimo podjęcia takiej próby.

W wyniku mediacji przewodniczącego Sądu Konstytucyjnego, Walerija Zorkina, przyjęto uchwałę o stabilizacji ustroju konstytucyjnego Federacji Rosyjskiej, która określiła termin referendum w sprawie zasad nowej konstytucji oraz ustaliła sposób zgłaszania kandydatury premiera. Prezydent miał prawo wybrać jednego z trzech kandydatów, którzy zostali wyłonieni w głosowaniu na Zjeździe. W ten sposób premierem został przedstawiciel nomenklatury z sektora paliwowo-energetycznego - Wiktor Czernomyrdin, co oznaczało kompromis z korpusem dyrektorskim wielkich przedsiębiorstw i odejście od restrykcyjnej polityki finansowej i równowagi budżetowej. Osłabiono także zapisy dotyczące wpływu NS na rząd. Zachowana natomiast została zasada konieczności uzyskiwania akceptacji NS na stanowiska premiera, ministra SZ oraz resortów siłowych.

Nie zakończyło to jednak kryzysu konstytucyjnego. Na VIII ZDL w marcu 1993 r. B. Jelcyn przedstawił propozycje niemożliwe do zaakceptowania przez Zjazd, aby - korzystając z ciągle znacznego poparcia społecznego - izolować deputowanych i ich lidera w społeczeństwie. Proponował odebranie ZDL roli najwyższego organu i przeprowadzenie referendum w sprawie zaufania do prezydenta, zasad nowej konstytucji i wyborów do parlamentu. Odbywający się wkrótce potem XI Zjazd nie zaakceptował kompromisu między B. Jelcynem i Rusłanem Chasbułatowem i próbował usunąć ich obu ze stanowisk, ale ostatecznie wyraził zgodę na referendum o zaufaniu do prezydenta i potrzebie przedterminowych wyborów prezydenta i deputowanych ludowych. Prezydent odniósł w referendum dość wyraźne zwycięstwo, zbyt małe jednak, aby doprowadzić do wyborów parlamentarnych.

Powołana wkrótce Narada Konstytucyjna rozpatrywała projekt ekspertów prezydenckich oraz nowy projekt NS. Projekt prezydenta zakładał ustanowienie republiki prezydencko-parlamentarnej, w której władza wykonawcza należała do prezydenta dysponującego prawem rozwiązywania parlamentu. Dwuizbowy parlament złożony z Dumy Państwowej i Rady Federacji miał kompetencje legislacyjne oraz prawo akceptowania prezydenckiego kandydata na stanowisko premiera i powoływania najwyższych stanowisk w organach sądowniczych. 
Konkurencyjny projekt NS przewidywał utworzenie republiki parlamentarnej, w której parlament miałby pełnię władzy ustawodawczej, prawo odwołania prezydenta oraz powoływania premiera i ministrów.

Istotną, choć niejednoznaczną rolę w walce prezydenta z Najwyższym Sowietem o formę ustrojową państwa odgrywały również władze lokalne. Były one na ogół przeciwne odtwarzaniu systemu jednolitej władzy sowieckiej i dążyły do maksymalnej samodzielności. W tym sensie były raczej sojusznikami prezydenta $\mathrm{w}$ walce z NS. Jednocześnie były zainteresowane stałym zwiększaniem dotacji budżetowych dla swoich regionów, co miało sens demoralizujący i czyniło z nich czynnik hamujący reformy. Z tego punktu widzenia władze lokalne były „,ideowo” zgodne z konserwatywnymi siłami NS. Jest rzeczą oczywistą, że w wyczerpującej konfrontacji z legislatywą prezydent nie mógł zrezygnować z potencjału poparcia, jaki mogły mu zaoferować władze regionalne. $Z$ tego względu postanowił on stworzyć nowy organ ustawodawczy w postaci Rady Federacji, w której reprezentowanych miałoby być po dwóch przedstawicieli każdego regionu. Taki projekt B. Jelcyn przedstawił Radzie Szefów Republik, ale nie mógł on być aktywnie forsowany, gdyż istniało w tym czasie zbyt wielkie ryzyko dezintegracji państwa ${ }^{16}$.

Jesienią 1993 r. sytuacja w państwie ewoluowała w takim kierunku, że przesilenie polityczne było już nieuchronne. Obóz antyreformatorski skupiony w NS, na czele $\mathrm{z}$ „triumwiratem”: Rusłan Chasbułatow - wiceprezydent gen. Aleksiej Ruckoj - przewodniczący Związku Przedsiębiorców i Przemysłowców, Arkadij Wolski, jednoczył się wokół haseł odbudowy Związku Sowieckiego i systemu sowietów. B. Jelcyn, mimo spadku poparcia w społeczeństwie dla programu reform liberalnych, niejako na przekór powołał ponownie na stanowisko premiera - J. Gajdara. Dnia 21 września 1993 r. ogłosił podpisanie dekretu nr 1400 o stopniowej reformie konstytucyjnej w Federacji Rosyjskiej, który rozwiązywał Zjazd Deputowanych Ludowych i Najwyższy Sowiet oraz wyznaczał na dzień 12 grudnia 1993 r. wybory do parlamentu nazwanego Zgromadzeniem Federalnym. Działania te doprowadziły do odmowy podporządkowania się dekretom prezydenckim przez NS i swoistej „wojny autorytetów”. NS podjął decyzję o odwołaniu B. Jelcyna, kwalifikując niekonstytucyjne działania prezydenta jako zamach stanu. Stanowisko to poparł Sąd Konstytucyjny. NS odwołał B. Jelcyna z funkcji prezydenta i zaprzysiągł na jego miejsce wiceprezydenta A. Ruckoja. Generał chciał wydawać rozkazy armii, ale rząd i ministerstwo obrony pozostały lojalne wobec B. Jelcyna. Zjazd Deputowanych Ludowych na posiedzeniu 23 września poparł decyzje NS. O wszystkim zdecydować

16 Tendencje separatystyczne pojawiały się nie tylko w Czeczenii czy w Tatarstanie. Gubernator obwodu swierdłowskiego, Eduar Rossel, nosił się z zamiarem utworzenia niezależnej republiki uralskiej i przystąpił nawet do produkcji własnego pieniądza - uralskiej marki. 
musiał w tym momencie nastrój społeczeństwa i jego reakcja na ewentualne użycie siły przez prezydenta, gdyż żadna ze stron konfliktu nie chciała już dyskutować nad kompromisem proponowanym przez prezesa SK, Walerija Zorkina, aby ZDL podjął decyzję o jednoczesnych wyborach prezydenta i parlamentu, po czym uległ samorozwiązaniu. Zablokowani w siedzibie NS - „Białym Domu” - deputowani sami przygotowali rozwiązanie siłowe oparte na akcji ulicznej swoich zwolenników. Podjęta 3 października próba zdobycia niektórych budynków państwowych zakończyła się niepowodzeniem i w znacznym stopniu odepchnęła od deputowanych ludzi z nimi sympatyzujących. Prezydent przy pomocy dekretów wprowadził stan wyjątkowy w Moskwie, rozwiązał sowiety i zdelegalizował organizacje opozycyjne. Ostatnim akordem było wprowadzenie do akcji wojska, które ostrzeliwało siedzibę NS i aresztowało deputowanych oraz popierających ich aktywistów opozycji nacjonalistycznej i komunistycznej. Był to definitywny koniec systemu sowietów i finał trwającej przez lata rywalizacji o kształt systemu politycznego i rolę prezydenta w FR. Został on sformalizowany dekretem B. Jelcyna z 7 października $1993 \mathrm{r}$. o reformie organów władzy przedstawicielskiej i samorządu lokalnego Federacji Rosyjskiej, który likwidował sowiety wszystkich szczebli z wyjątkiem rejonowego (najniższego). Dekret ten dla republik-podmiotów FR miał charakter fakultatywny ${ }^{17}$. Do czasu zwołania Zgromadzenia Federalnego w grudniu 1993 r. prezydent przejął kompetencje dotychczasowych organów ustawodawczych w całej sferze społecznoekonomicznej i finansowej ${ }^{18}$.

Prezydent zdecydował się na połączenie opartych na demokratycznych zasadach (z wyłączeniem ugrupowań ekstremistycznych) wyborów do Zgromadzenia Federalnego z referendum konstytucyjnym. Mimo dość słabego wyniku wyborczego ugrupowań demokratycznych społeczeństwo poparło projekt nowej konstytucji (58,4\% przy frekwencji 54,3\%). Ugrupowania opozycyjne wobec prezydenta (jak LDPR Władimira Żyrinowskiego, komuniści, agraryści), zachęcone dobrym rezultatem w wyborach, również zaakceptowały projekt konstytucji, widząc szanse na walkę o własne cele polityczne w ramach nowego systemu ustrojowego z silną pozycją prezydenta ${ }^{19}$.

\footnotetext{
17 W. Marciniak, op.cit., s. 537.

18 S.A. Awakian, Prezident Rossijskoj Federacji. Ewoliucyja konstitucyonnoprawowogo statusa, „Wiestnik Moskowskogo Uniwersitieta" nr 1, Moskwa 1998.

${ }^{19}$ W. Marciniak, op.cit., s. 554-555. W części niniejszego artykułu poświęconej powstaniu instytucji prezydenta FR została także wykorzystana niepublikowana praca magisterska G. Wilgi, Kształtowanie się instytucji Prezydenta Federacji Rosyjskiej w latach 1988-1993, Wydz. Orientalistyczny UW, 2008.
} 


\section{Konstytucyjne umocowanie i stabilizacja systemu prezydenckiego w FR}

Sformułowania zawarte w Konstytucji Federacji Rosyjskiej 1993 r. należą do klasyki europejskiego prawa państwowego i praktyki ustrojowej. FR została określona jako państwo demokratyczne o republikańskiej formie rządów i federacyjnej strukturze państwa. Zasadą ustrojową jest podział władz na ustawodawczą, wykonawczą i sądowniczą. Władzę ustawodawczą sprawuje dwuizbowe Zgromadzenie Federalne złożone z Dumy Państwowej i Rady Federacji, które mianują przedstawicieli najwyższych organów wymiaru sprawiedliwości. Władza wykonawcza należy do Rządu FR (art. 110). Z drugiej jednak strony pozycja prezydenta posiada tu charakter wyjątkowy wobec rozwiązań powszechnie stosowanych w praktyce ustrojowej. Instytucja prezydenta nie jest zaliczana do żadnej z gałęzi władzy, lecz w istocie stoi ponad nimi. Prezydent jest tu traktowany jako gwarant konstytucji i prawidłowego funkcjonowania systemu władzy. Określa on główne kierunki polityki wewnętrznej i zagranicznej oraz czuwa nad przestrzeganiem praw i swobód obywatelskich. Egzekutywa podlega prezydentowi, gdyż mianuje on i odwołuje premiera i członków rządu, do czego potrzebuje tylko akceptacji Dumy Państwowej. Opór Dumy jest tu mało prawdopodobny, gdyż w przypadku obstrukcji nominacji premiera może on rozwiązać Dumę. Prezydent może także uchylać akty prawne wydawane przez rząd, ma prawo przewodniczyć jego posiedzeniom i wydawać mu instrukcje. Organami prezydenta są jego administracja oraz Rada Bezpieczeństwa, przy pomocy których inicjuje on własną działalność w polityce wewnętrznej i zagranicznej oraz kontroluje działalność Dumy i rządu. Prezydent dominuje również wyraźnie nad Dumą Państwową. Posiada prawo inicjatywy ustawodawczej, podpisuje ustawy i ma prawo weta wobec aktów prawnych proponowanych przez legislatywę oraz badania zgodności ustaw z konstytucją za pośrednictwem Sądu Konstytucyjnego. W konstytucji zachowane jest prawo usunięcia prezydenta ze stanowiska przez Zgromadzenie Federalne w przypadku zdrady stanu lub ciężkiego przestępstwa, ale jest ono obwarowane bardzo wysokimi wymogami formalnymi związanymi z decyzjami Dumy, Sądu Konstytucyjnego i Sądu Najwyższego oraz wymogiem zdobycia dla takiej decyzji większości dwóch trzecich w Radzie Federacji. Duma ma prawo badać zgodność z prawem dekretów prezydenckich i większością dwóch trzecich odrzucić weto prezydenckie wobec uchwalonych przez nią ustaw. Prezydent sprawuje funkcje legislacyjne poprzez wydawanie dekretów i rozporządzeń, przy czym obszary kompetencji prezydenckich i Dumy nie są wyodrębnione, co teoretycznie może prowadzić do konfliktu kompetencyjnego. 
Taka konstrukcja systemu władzy w Rosji wskazuje wyraźnie, że prezydent nie tylko wykorzystał cały potencjał polityczny, jaki gromadzony był w tej instytucji w czasie walki z systemem Sowietów i w procesie uzyskiwania nadzwyczajnych pełnomocnictw, ale także po próbie puczu 1993 r. jeszcze bardziej umocnił swoje prerogatywy wobec pozostałych organów państwa, zatwierdzając je w Konstytucji FR.

Rosyjski półprezydencki system prawnoustrojowy i funkcje prezydenta w tym systemie porównywane bywają z systemem francuskim. Mimo pewnych podobieństw porównanie takie jest jednak nieuprawnione ze względu na zupełnie odmienny poziom rozwoju instytucji demokratycznych i społeczeństwa obywatelskiego w obu państwach. Nawet jeśli określona sytuacja polityczna we Francji podczas powrotu prezydenta de Gaulle’a do władzy sprzyjała przyjęciu konstytucji zapewniającej mu duży zakres władzy wykonawczej i silną pozycję wobec Zgromadzenia Narodowego, to jednak trudno to porównać $\mathrm{z}$ autorytarnym systemem w konwulsjach wyłaniającym się w Rosji, z rażącym łamaniem prawa, a nawet przemocą, by pozbyć się dziedzictwa totalitarnej rzeczywistości funkcjonującej w tym kraju przez ponad siedemdziesiąt lat.

Konstytucyjnie określony zakres władzy prezydenta Rosji tworzył oczywiście tylko ramy prawne, które konkretną treścią wypełniała praktyka polityczna. Uwzględniając rosyjską i sowiecką tradycję polityczną, do której należało skupienie ogromnej władzy w rękach jednostki, a także specyficzną dynamikę procesu dochodzenia do określenia uprawnień nowej głowy państwa, siłą zdobywającą je na politycznie i moralnie zdominowanych rudymentach starego systemu, możemy sobie uświadomić, że prezydent FR mógł w praktyce znacznie wyjść poza literę i ducha konstytucji, nie będąc narażonym na szczególnie dotkliwą krytykę ze strony społeczeństwa i przedstawicieli pozostałych gałęzi władzy. Opis i szczegółowa charakterystyka rozwoju sytuacji politycznej w Rosji, w całym okresie obejmującym funkcjonowanie rosyjskiej prezydentury, nie mieści się w ramach tego opracowania. Można jednak wskazać na najważniejsze elementy charakteryzujące sposób korzystania prezydentów - B. Jelcyna i W. Putina z przyznanej im władzy.

Szereg obiektywnych i subiektywnych czynników spowodowało, że B. Jelcynowi bardzo trudno było utrzymać przez dłuższy czas poparcie społeczne dla swojego kursu politycznego. Przede wszystkim wpływał na to fakt, iż beneficjentami reform rynkowych oraz demokratyzacji życia i politycznego otwarcia na świat była stosunkowo niewielka część społeczeństwa, przy drastycznym zubożeniu przytłaczającej części Rosjan. Prywatyzacja w rosyjskim modelu doprowadziła do powstania systemu oligarchicznego, który obywatelom kojarzył się z grabieżą mienia państwowego i niesprawiedliwym podziałem dóbr. Otwarcie na Zachód, przyznanie się do przegranej w zimnej wojnie było traktowane jako dyskredytacja rdzennych rosyjskich 
wartości moralnych, klęska w wielkiej grze geopolitycznej i utrata dumy z mocarstwowego statusu państwa.

Drugim ważnym elementem był brak postępów w reintegracji przestrzeni postsowieckiej w ramach WNP, a także występowanie zjawisk separatyzmu w ramach samej Federacji Rosyjskiej. Hasło B. Jelcyna skierowane do regionów, których poparcie było mu niezbędne, brzmiało: „Bierzcie tyle samodzielności, ile zdołacie udźwignąć”. O ile kryzys na tym polu w stosunkach z Tatarstanem czy Baszkirią udało się powstrzymać dzięki podpisaniu umów o rozgraniczeniu pełnomocnictw między federalnym centrum a tymi podmiotami federacji, o tyle separatystyczne tendencje Czeczenii podgrzewane przez rosyjski nacjonalizm, reprezentowany przez mającą duże wpływy w Dumie tzw. „partię wojny”, doprowadziły do wybuchu wojny domowej na części obszaru FR, grożąc rozlaniem się konfliktów polityczno-etnicznych na cały Północny Kaukaz. Wojna ta przyniosła straszne żniwo w postaci ofiar ludzkich i ogromnych zniszczeń, nie przynosząc jednak definitywnego rozstrzygnięcia.

Należy także dostrzegać wpływ czynników osobowościowych charakteru prezydenta na jego społeczną recepcję. B. Jelcyn wielokrotnie narażał na szwank reputację swojego urzędu. „Familia” Jelcyna stała się symbolem prywaty i nieprzejrzystości mechanizmów władzy, często zachowywał się on w kompromitujący sposób, a wreszcie, dotknięty ciężką chorobą, sprawiał wrażenie człowieka niezdolnego do wykonywania funkcji głowy państwa.

Pomimo tak niekorzystnego scenariusza tej prezydentury przyznane prezydentowi prerogatywy pozwalały utrzymać władzę przez niemal całą dekadę i zrzec się jej w honorowy sposób 31 grudnia 2000 r. Jego olbrzymie uprawnienia i brak kontroli ze strony innych organów władzy umożliwiały mu wykorzystywanie tzw. „resursu administracyjnego", to jest państwowych środków, na prowadzenie kampanii wyborczej, wpływ polityczny na media państwowe i prywatne uzyskany dzięki decyzjom prywatyzacyjnym korzystnym dla popierających go grup itd. W ten sposób w wyborach prezydenckich 1996 r., do których startował z 3\% poparciem, potrafił on pokonać najgroźniejszych rywali z liderem KPFR, Gienadijem Ziuganowem, na czele, przejmując w drugiej turze elektorat gen. Aleksandra Lebiedzia.

Obszerne kompetencje instytucji prezydenta w pełni zdołał jednak wykorzystać dopiero W. Putin, który swą kadencję rozpoczął w maju 2000 roku. 


\section{The issue of president in the political system of the Russian Federation}

This article presents the course that passed the political system of USSR going from the old soviet structure to the modern form of the state. Total economic and political crisis forced the last General Secretary of the Communist Party Mikhail Gorbatchev to seek the new political institutions and were helpful in the process of maintaining socialist character of the state and social relations and, simultaneously, to carry out the changes of the political system which became necessary.

These efforts were a failure because of strong resistance, on the one hand, communist nomenklatura and the other hand, the new democratic movement in the Russian Federation conducted by Boris Yeltsin and independent movements in Soviet Republics. After the trial to stop the process of reforming of the state undertaken by communist leaders of USSR during coupé d'etat in August 1991 the initiative passed to the democratic forces in Russia.

The fall of the USSR and foundation of the CIS as the platform of the reintegration of Post-Soviet area started the new stage of the political conflict in the Russian Federation. The objective needs occurred in the process of reforming of the economic structures, growing of the protest attitudes, necessity to relief the mood of the local authorities in order to attain their support for the course of modernization, pushed President Yeltsin to concentrate enormous power. The old Soviet Constitution was more comfortable for such political conditions than modern solutions based on the power's division in three branches - Parliament, Government and independent jurisdiction.

Contradictions of the Post-Soviet period brought to the deep conflict between President Yeltsin and Supreme Soviet in October 1993. The defeat of the conservative forces in this confrontation meant the end of Soviet system in Russia, however political system that was created on such ground had authoritarian features, which was used all Yeltsin's presidential decade bringing, as a result, the system very far to the principles of the democracy.

\section{Le Président dans le système politique de la Fédération de Russie}

Larticle présente la transformation du système politique russe de l'ancienne URSS en un État moderne. La crise économique et politique a forcé le dernier secrétaire général du Parti communiste de l'Union soviétique, Mikhaïl Gorbatchev, à chercher les nouvelles institutions politiques nécessaires pour 
maintenir le caractère socialiste de l'État et à mener les changements du système politique.

D’une part, ces efforts ont échoué en raison de la forte résistance de la «nomenklatura», et d'autre part à cause d'un mouvement démocratique en Fédération de Russie mené par Boris Eltsine et des mouvements indépendantistes se manifestant dans les républiques soviétiques. Après avoir essayé d’arrêter le programme de réformes par les dirigeants communistes de l'URSS au cours du coup d'État en août 1991, les forces démocratiques russes ont pris l'initiative.

La chute de l'URSS et la fondation de la Communauté des États indépendants (CEI) comme la plate-forme de la réintégration de la zone post-soviétique ont commencé la nouvelle phase du conflit politique en Fédération de Russie. Les besoins qui sont apparues lors du processus de réforme des structures économiques du pays, l'augmentation des attitudes défavorables, la nécessité d'atteindre le soutien des autorités locales pour le programme de modernisation ont poussé le Président Boris Eltsine à concentrer beaucoup de pouvoir dans ses mains. L'ancienne Constitution soviétique était plus efficace pour une telle situation politique que des solutions modernes fondées sur le principe de la division du pouvoir en trois branches (parlement, gouvernement et juridiction indépendante).

Les contradictions de la période post-soviétique ont contribué au conflit profond entre le Président Eltsine et le Soviet suprême en octobre 1993. La défaite des forces conservatrices dans cette confrontation signifiait la fin du système soviétique en Russie, mais le nouveua système politique créé sur un tel terrain avait des traits autoritaires et était très loin de la démocratie. 